\title{
Morphological characteristics of the sinus node on postmortem tissue
}

\author{
F.V. Perde ${ }^{1}$, A. Atkinson², J. Yanni², D. Dermengiu1', H. Dobrzynski² \\ 1 Prosecture Department, National Institute of Legal Medicine, Bucharest, Romania \\ 2University of Manchester, Manchester, United Kingdom
}

[Received: 14 June 2015; Accepted: 11 August 2015]

\begin{abstract}
The sinus node is an intensively researched structure in terms of anatomical, histological, electrophysiological, molecular and genetic approach. For postmortem diagnosis it is still difficult to investigate due to a still reduced accessibility. In this study we tried and succeed to apply molecular biology techniques on postmortem tissues in order to widen the range of postmortem forensic investigation and provide information related to the diagnostic of cardiac arrhythmia. We described the stages of this investigation, with dissection, preservation and analysis that included classical histology, immunohistochemistry, confocal microscope, microdissection, RIN testing, mRNA expression obtaining a precise morphofunctional location of the sinus node. (Folia Morphol 2016; 75, 2: 216-223)
\end{abstract}

Key words: messenger RNA, autopsy, connexin 43

\section{INTRODUCTION}

With the discovery in 1907 by Arthur Keith and Martin Flack [14], sinus node (SN) was a favourite structure of scientific research on several areas, such as cardiology, electrophysiology and pathology. It was described as a banana-shaped spindle structure, located $1 \mathrm{~mm}$ beneath epicardium, in the sinus venous wall of the atrium at the junction between the superior vena cava (SVC) and right atrium, lateral to crista terminalis with a size approximately 2-3 $\mathrm{mm}$ thickness and 10-20 $\mathrm{mm}$ long [9]. The vascularisation of $\mathrm{SN}$ is provided by homonym artery that originated in most cases from the right coronary artery, and after an upward trajectory beneath right atrial appendage and a clockwise or counter-clockwise direction around the lower portion of the SVC, is reaching finally the $\mathrm{SN}$ area [1, 23]. Histologically, the SN cells are mainly located circumferentially or adjacent to SN artery, being included in a rich matrix of connective tissue with insulation properties. Although being muscle cells, nodal cells are smaller and paler than the working atrial cells and have very low sarcomeres and mitochondria [8].
Embryologically, SN cells are considered to be immature cardiomyocytes left in an early stage of development $[7,13]$. Electrophysiologically, they have spontaneous depolarisation and low contractile properties, being electrically more isolated from the rest of atrial myocardial work cells. Thus, they express specific ion channels involved in spontaneous depolarisation (e.g. HCN4), lack high speed gap junctions found in Purkinje fibres (e.g. connexin 40 [Cx40] and connexin 43 [Cx43]) and working myocardium (e.g. $\mathrm{Cx} 43)$, being present lower conductivity junctions in relatively lower quantity (e.g. connexin 45 [Cx45]). In contrast to fibroblasts, SN cells do not have proteins involved in the organisation of cell membrane as caveolin 3 (Cav3) $[3,4,17]$.

Although the scientific aspects listed above are very well characterised on lab animals and transplanted heart tissue $[5,6]$, studies assessing these issues on human tissue are still scarce or even absent.

On the human autopsy tissue, inevitably affected by post-mortem degradation, the messenger RNA (mRNA) expression yielded results that allowed qualitative and

Address for correspondence: Dr F.V. Perde, National Institute of Legal Medicine, Vitan-Barzesti 9, sector 4, 042122 - Bucharest, Romania, e-mail: filipvirgil@gmail.com 
quantitative determination of gene expression in the various tissues of the body $[2,10,12,21,24]$. Among those, the cardiac tissue has been preferentially studied because of its involvement in the diagnosis of sudden cardiac death and a higher resistance to autolysis like any muscle tissue [11, 19, 22].

Correlating the scientific literature regarding the cardiac conduction system cell biology and postmortem molecular investigation, we found that the gene expression of mRNAs specifically localised at the SN on autopsy tissue has not been yet addressed.

The aim of this study was to visualise and characterise the macroscopic and microscopic morphology of the $\mathrm{SN}$ on autopsy tissue and test the feasibility of molecular investigation, by highlighting the differences between the $\mathrm{SN}$ and the surrounding atrial muscle.

\section{MATERIALS AND METHODS}

\section{Specimen collection}

We analysed 4 human SN autopsy samples obtained from National Institute of Legal Medicine, Bucharest, Romania. With the intention of preserving the molecular expression and avoiding at maximum the autolysis, we selected cases with traumatic death, a relatively short postmortem interval (between $10 \mathrm{~h}$ and $30 \mathrm{~h}$ ), and young age (under 30 years). We excluded any kind of documented cardiovascular pathology, macroscopic or microscopic pathological features, diabetes, lethal intoxication, chronic diseases, and hospitalisation. The ethical and legal requirements related to postmortem human tissue testing were respected.

\section{Heart investigation and dissection}

In order to obtain an anatomically complete SN area we dissected a square sample approximately $5 / 5 \mathrm{~cm}$ of atrial wall, centred by crista terminalis, with atrial appendage superiorly and $1-2 \mathrm{~cm}$ of pectinate and SVC sinus on each side of crista terminalis included. The techniques described here are adapted from Chandler et al. [6]

The SN sample was removed at autopsy and immediately immersed in isopentane previously cooled at $-65^{\circ} \mathrm{C}$, then stored in freezer, at $-65^{\circ} \mathrm{C}$. The samples were further analysed at University of Manchester, Institute of Cardiovascular Sciences. Preparations were cryosectioned at $20 \mu \mathrm{m}$ thicknesses and every section collected and mounted onto SuperFrost Plus slides.

\section{Histology, IHC}

Serial sections we used for identification with Masson's Trichrome staining and afterwards consecutive sections with IHC staining with primary antibody (rabbit polyclonal IgG, produced by Almone labs at 1:50 concentration) and secondary antibody (lgG, host - donkey, against rabbit conjugated with FITC green (fluorescein isothiocyanate - 490 excitation and 520 emission wavelength), at 1:100 concentration, produced by Millpore). The neighbouring sections were used for RNA extraction. The sections were fixed and permeabilised by treating them with methanol at $-20^{\circ} \mathrm{C}$, and washed three times in $0.01 \mathrm{M}$ phosphate buffer saline (PBS) containing: $\mathrm{NaCl}$ $0.138 \mathrm{M}, \mathrm{KCl} 0.027 \mathrm{M}, \mathrm{pH} 7.4$ (Sigma). The sections were then blocked with $1 \%$ bovine serum albumin (BSA) in PBS for $1 \mathrm{~h}$ at room temperature and then incubated with the primary antibodies overnight. Antibodies were diluted $1: 50$ in 1\% BSA in PBS. On the following day, the sections were washed 3 times in PBS and incubated with anti-rabbit and anti-mouse secondary antibodies conjugated to either FITC (Chemicon) or Cy3 (Chemicon) for 1-2 $\mathrm{h}$ at room temperature. Secondary antibodies were diluted to $1: 100$ in 1\% BSA in PBS. After washing 3 times in PBS over 30 min, coverslips were mounted onto the slides using Vectashield T-1400 (Vector Laboratories). Signal was detected using a confocal microscope (Zeiss LSM5, Carl Zeiss Microscopy) with Pascal software (Zeiss Microscopy). The excitation wavelength used was $488 \mathrm{~nm}$ for FITC and $550 \mathrm{~nm}$ for Cy3.

\section{RNA integrity number, microdissection, RT-qPCR, mRNA}

We tested the integrity of the RNA using Agilent NanoLabChips run on Agilent 2100 Bioanalyser, whereby, each Nanochip is pre-loaded with a gel-dye mix to fill the microchannels. $1 \mu \mathrm{L}$ of each RNA sample is loaded into 1 of 12 wells in the NanoLabChips as well as a standard ladder (RNA 600 ladder). The dye contained within the microchannels intercalates with the RNA and an electropherogram plot of the RNA is obtained. This allows the $18 \mathrm{~S}: 28 \mathrm{~S}$ ratio to be obtained, and provides a numerical value (out of 10, 1 being completely degraded RNA) interpreted from the amount of interfering noise peaks between $18 \mathrm{~S}$ and $28 \mathrm{~S}$ peaks.

For RNA extraction, the sections were placed in absolute ethanol and micro-dissected under light microscope. Total RNA was isolated from the micro-dissected tissue using an RNeasy Micro kit (Qiagen) according to the manufacturer's recommended protocol. The RNA concentration was measured using a Nanodrop spectrophotometer (Labtech International). $530 \mathrm{ng}$ of total RNA from each sample was reverse transcribed with Superscript III reverse transcriptase (Invitrogen) 
in a $20 \mu \mathrm{L}$ reaction according to the manufacturer's instructions, using random hexamer priming. Aliquots of the resulting CDNA were diluted 35-fold in water for direct use in $\mathrm{QPCR}$. The relative abundance of selected CDNA fragments was determined with qPCR using an ABI 7900HT instrument (Applied Biosystems) with Power SyBr green (Applied Biosystems) and QuantiTect primer assays (Qiagen) or custom-designed primers in $10 \mu \mathrm{L}$ reactions. All runs were 40 cycles in duration. For all mRNAs in each sample, at least 3 separate measurements were made with $1 \mu \mathrm{L}$ aliquots of each cDNA sample and a sample PCR product for each mRNA was run on a DNA gel to check that it was the correct band size. Average cycle threshold $(\mathrm{Ct})$ values were used in the $\mathrm{E}-\Delta \mathrm{Ct}$ (E = efficiency of the PCR reaction) calculation. The ribosomal $28 \mathrm{~S}$ reference gene was used to normalise the data. Outliers were excluded from the statistical analysis. These were determined using a robust statistical modified z-score method based on the median of absolute deviation.

Signal intensity measurements were then measured using Volocity software (Improvision) after background and autofluorescence correction. Semi quantitative determination of immunofluorescence signals was made using Volocity software, with the same parameters for all the samples. The detections were made with confocal microscope and Axiovision software. Significant differences in the abundance of mRNAs and proteins expression by immunohistochemistry in different tissues were identified using Excel from Microsoft Software 2010 with unpaired t-tests, when $p<0.05$.

\section{RESULTS}

\section{Macroscopic identification, dissection}

After the correct detachment, the classic front view of the heart does not give us useful information (Fig. 1), only the posterolateral and superior surface of the right atrium (Figs. 2, 3) identifies the atrial wall landmarks for dissection: sinus venarum (located between SVC and inferior vena cava) separated from atrial wall muscle by sulcus terminalis (which has a correspondent on crista terminalis endocardium [Figs. 4, 5]). The SN specimen, on endocaridal face shows from left to right sinus venarum, crista terminalis and pectinates muscle which continues superiorly with right atrial appendage (Fig. 5).

\section{Direct observation and low magnification: observation of SN artery and surrounding tissue}

The cross section perpendicular on crista terminalis was the reference image in this study, useful for high-

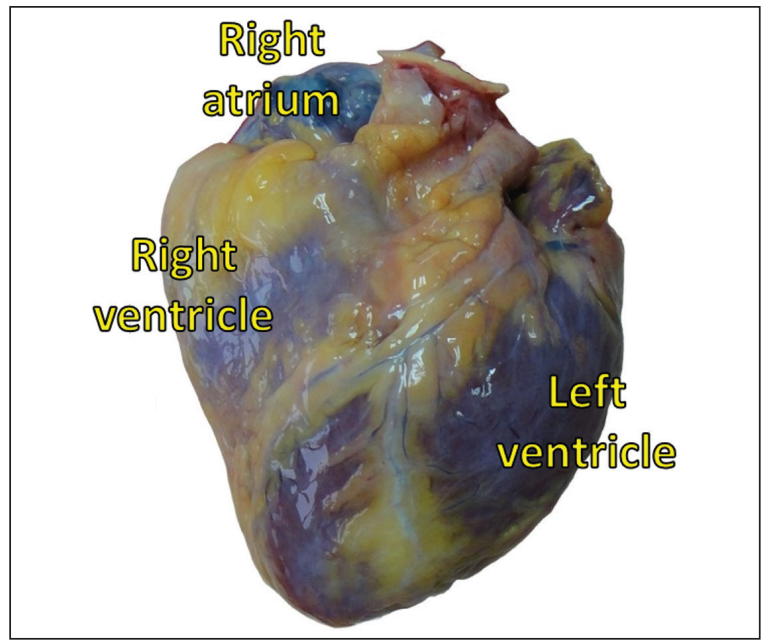

Figure 1. Whole heart fresh specimen — antero-superior view.

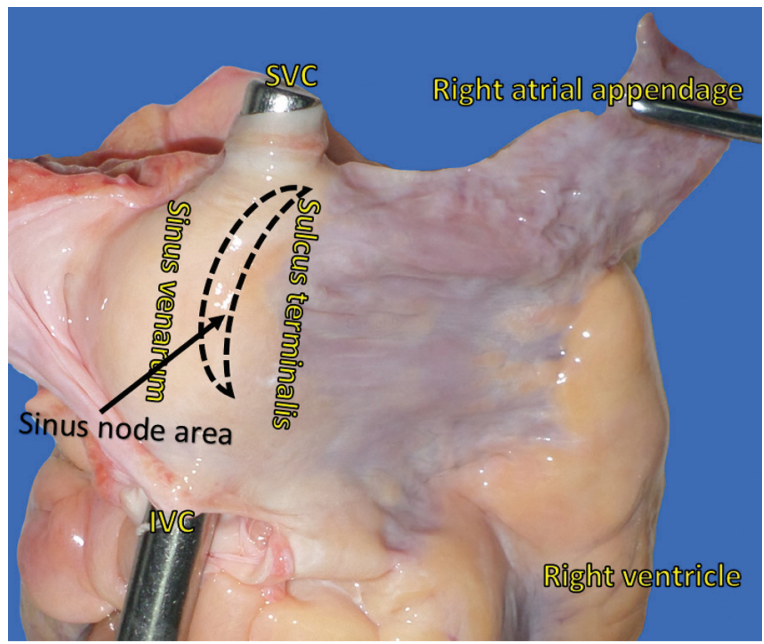

Figure 2. Postero-lateral face right atrium with a metal cylinder through inferior and superior vena cava (SVC) and the traction of right atrial appendage.

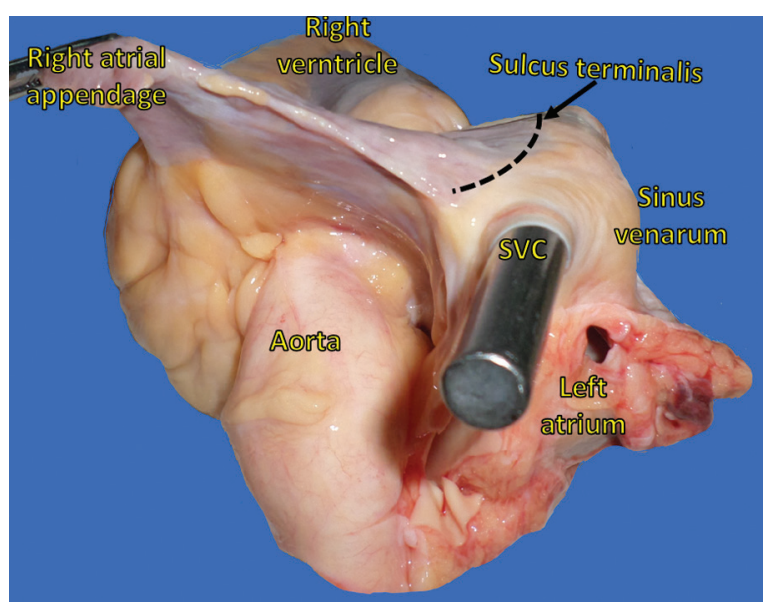

Figure 3. Upper face of right atrium with a metal cylinder through inferior vena cava and superior vena cava (SVC) and the traction of right atrial appendage. 


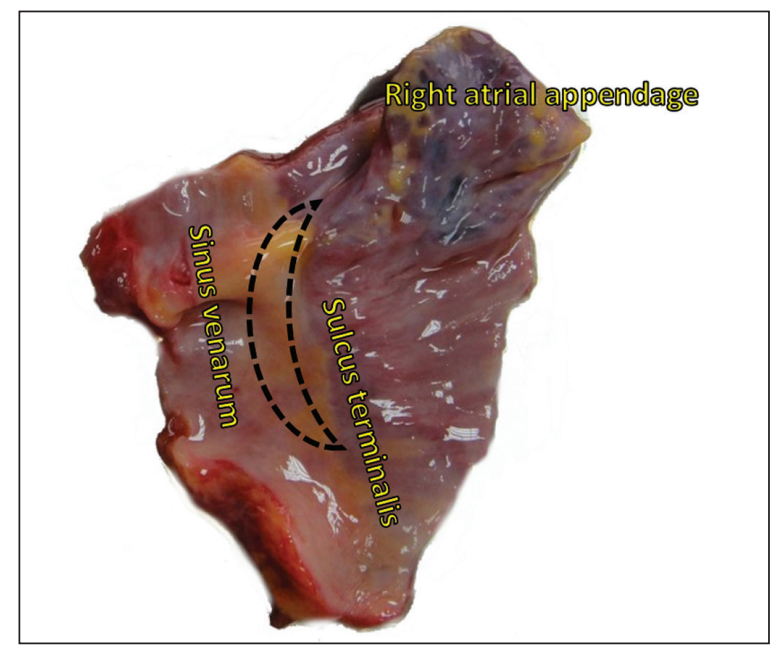

Figure 4. Sinus node fresh preparation, epicardial view, with (from left to right) sinus venarum, sulcus terminalis, pectinate muscles and right atrial appendage.

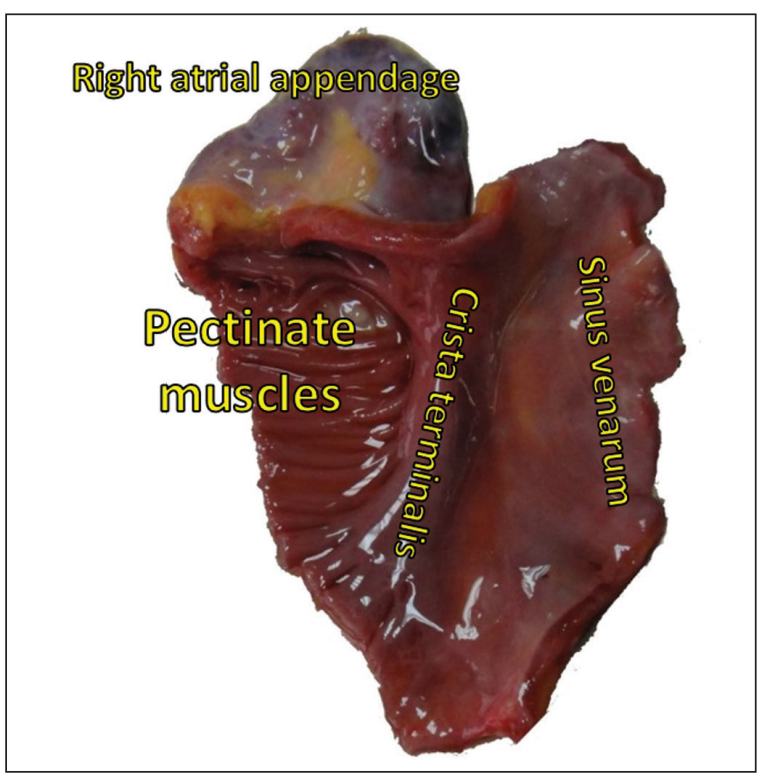

Figure 5. Sinus node fresh preparation, endocardial view with (from left to right) pectinate muscles, right atrial appendage, crista terminalis and sinus venarum.

lighting the structures adjacent to $\mathrm{SN}$ artery: pectinates muscles, crista terminalis, and SN area. We have made a comparison between similar samples, at the same level, with different techniques:

- fresh section that allows direct visualisation of the SN artery as a red dot of blood expressed after compression (Fig. 6);

- frozen section (Fig. 7);

- direct observation by reflected light - useful for further microdissection (Fig. 8);

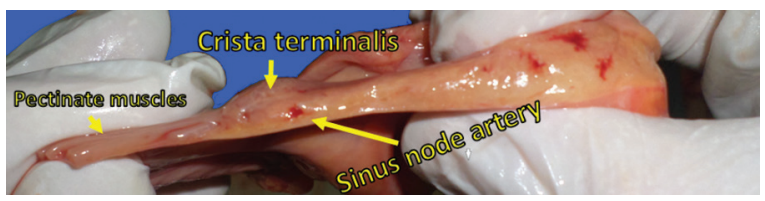

Figure 6. Autopsy sample of sinus node - transversal section perpendicular to crista terminalis: the squeezed and tractioned tissue shows (from left to right) pectinate muscles, crista terminalis, the red spot that indicates the sinus node artery, sinus venarum; Up: endocardium; Bottom: epicardium.

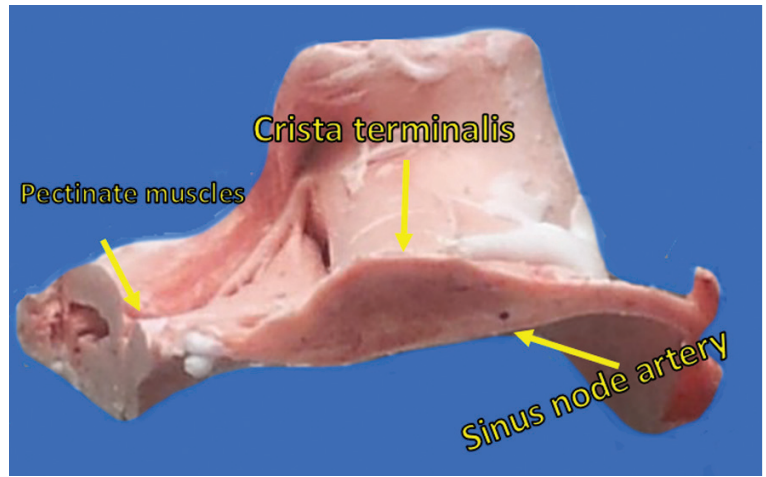

Figure 7. Frozen transversal section of the sinus node sample (from left to right): pectinate muscles, crista terminalis, the sinus node artery, sinus venarum; Up: endocardium; Bottom: epicardium.

- Trichrome Masson staining, magnifying glass (Figs. 8, 9);

- IHS staining, double labelling Cx43 and Cav3, epifluorescence (Figs. 10, 13).

\section{High power magnification: comparison between} $\mathrm{SN}$ and surrounding tissue

Sections at high magnification (40x and $63 \times$ ) allow visualisation of cellular details and a marked differentiation of cell types:

- Trichrome Masson staining of the SN and atrial muscle $63 \times$ magnification (Figs. 11A, B): the SN cells are smaller, paler embedded in rich matrix of connective tissue; the working myocytes are bigger, with less connective tissue, more stained;

- confocal microscope with double labelling (Figs. 12, 13C): Cav3 stained the membranes (red) and $\mathrm{C} \times 43$ the GAP junctions (green);

- epifluorescence microscope with double labelling (Fig. 13B): lower detail due to signal summation;

- semiquantification of $\mathrm{C} \times 43$ expression at $\mathrm{SN}$ compared to atrium muscle (Fig. 14): $\mathrm{C} \times 43$ has an obvious higher expression in $\mathrm{SN}$ compared to crista terminalis. 


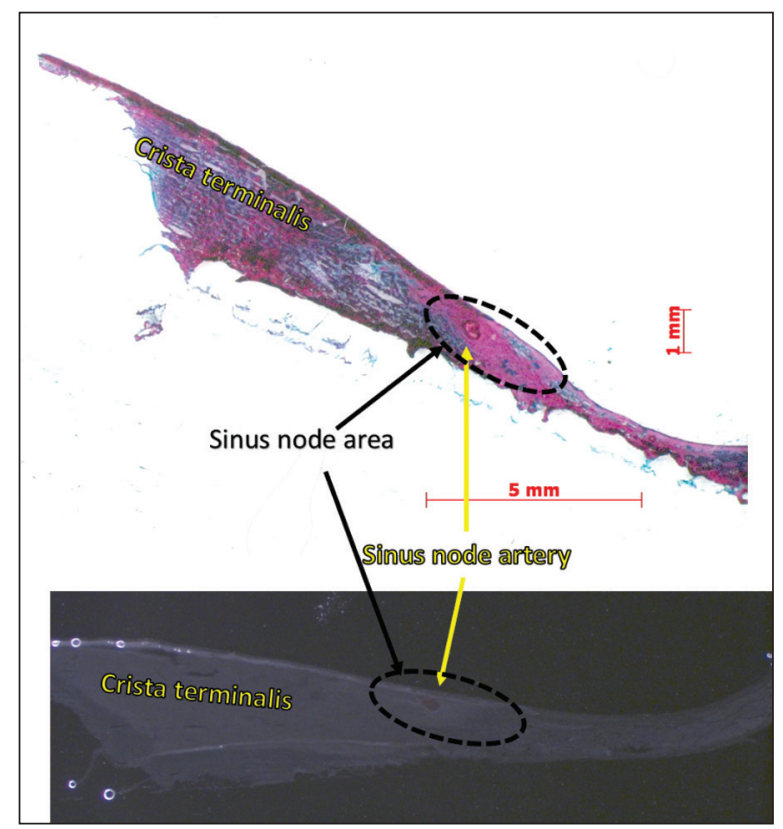

Figure 8. Sinus node - Pan-scan Trichrome Masson and Transluminescence - same sample as previous - sinus node; Up: epicardium; Bottom: endocardium.

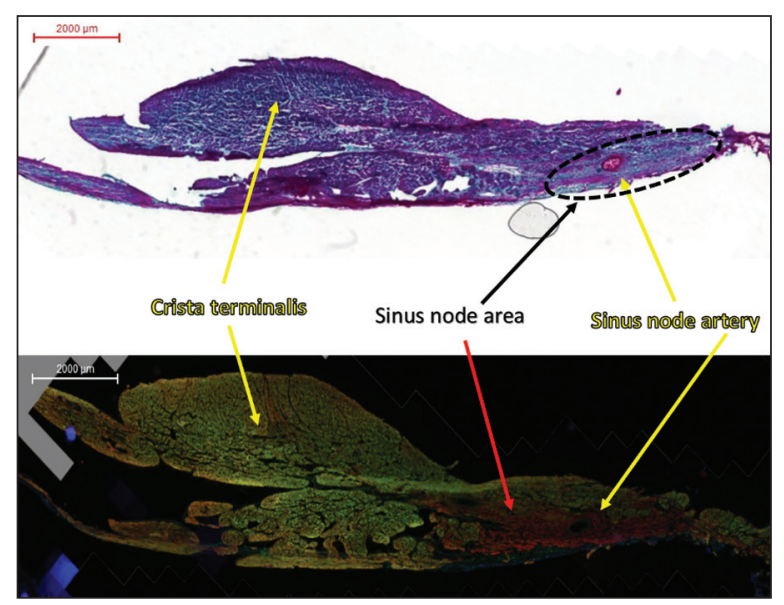

Figure 9. Pan-scan 10× Trichrome Masson and Pan-scan 10× IHC - same sample as previous, dual labelling connexin 43 an caveolin 3; Up: endocardium; Bottom: epicardium.

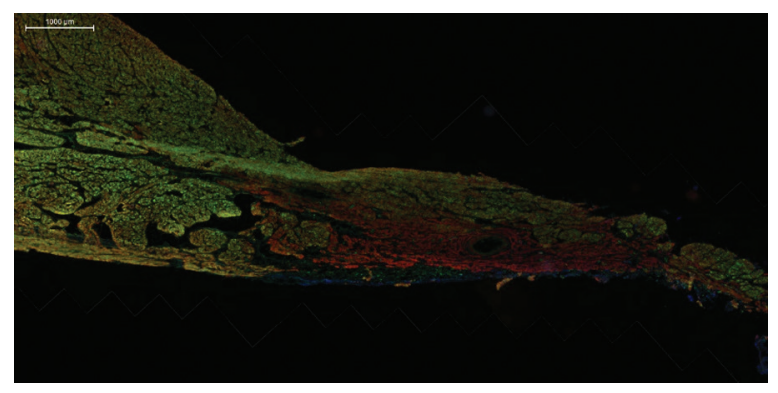

Figure 10. Connexin 43/caveolin 3 expression - detail; Up: endocardium; Bottom: epicardium.
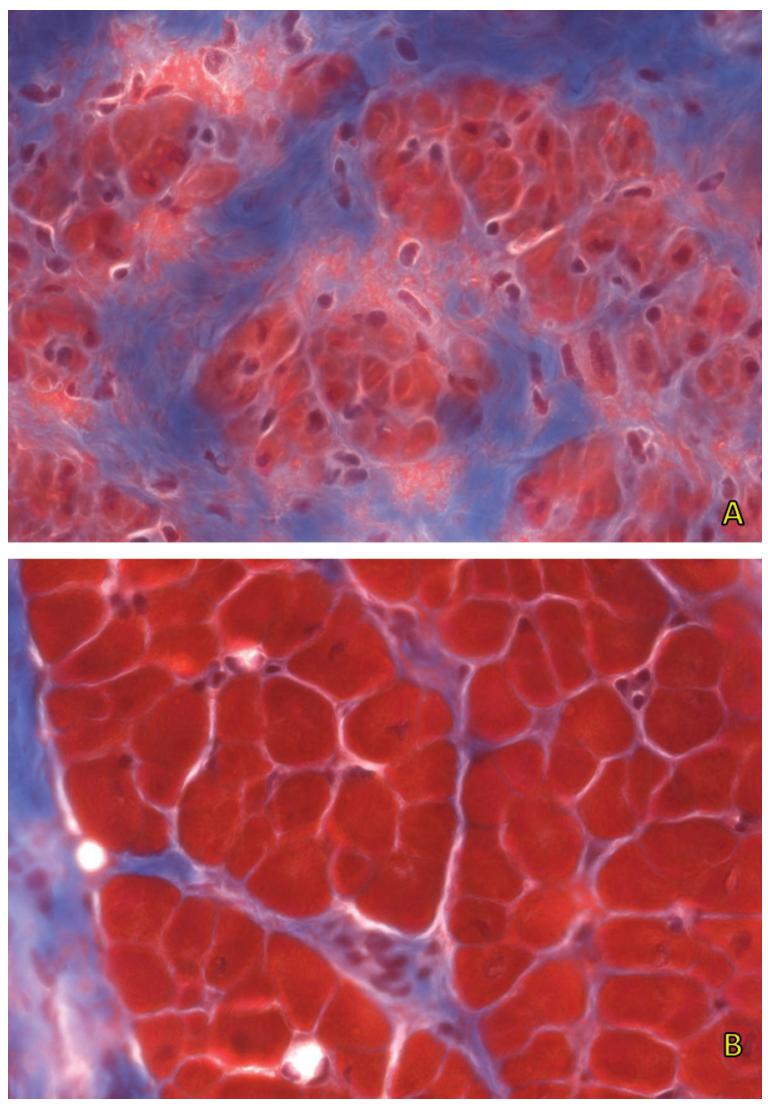

Figure 11. A. Sinus node; B. Atrium wall — crista terminalis (63×, Trichrome Masson).

\section{Molecular diagnosis: mRNA integrity and Cx43 expression}

For a molecular diagnosis we calculated the mRNA integrity number (RIN) for each sample obtaining the results shown in Figures 15 and 16. Afterwards, we measured the mRNA expression of $\mathrm{Cx} 43$ in $\mathrm{SN}$ and atrium muscle obtaining a significant lower value of Cx43 in SN (Fig. 17).

\section{DISCUSSION}

Through this study we succeeded to apply previous tested techniques on lab animals and transplanted heart tissue in order to make a morpho-functional differentiation of the SN compared with atrial muscle. We also proved that the mRNA has not only a good quality but also permitted further analysis like microdissection. We showed at the $\mathrm{SN}$, identified by histology and immunohistochemistry, a significant lower genetic expression of Cx43 which is a valuable confirmation of the methods used.

Withal, we have some observations that need to be mentioned: 

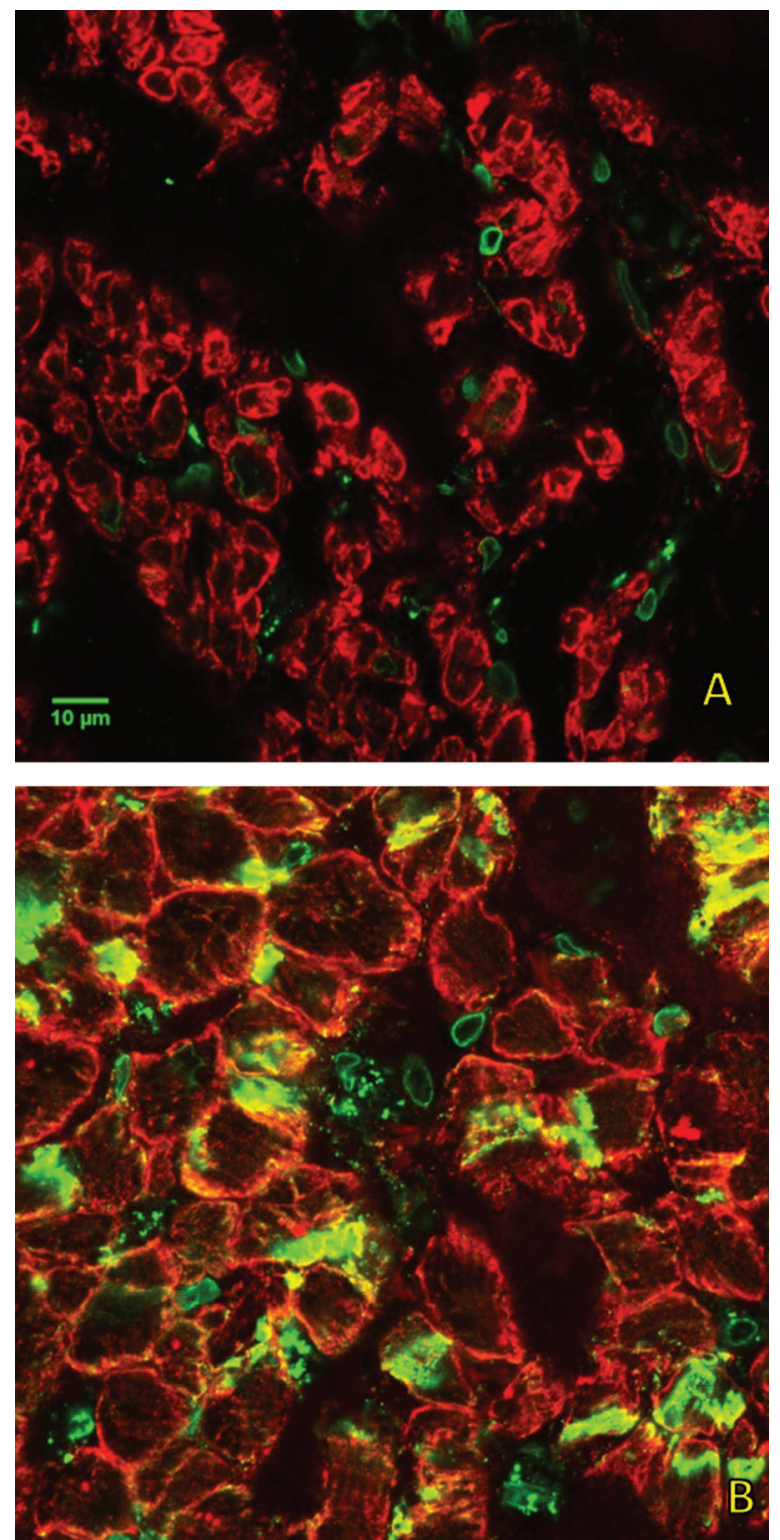

Figure 12. Double labelling, connexin 43 (green) and caveolin 3 (red); A. Sinus node; B. Transversal section of atrial muscle.

- SN dissection was necessary not to affect and not be affected by heart dissection (coronaries, heart valves, myocardium etc.). To be able to highlight the SN is necessary to cut the great vessels and pericardium at as far as possible from crista terminalis (at least $2 \mathrm{~cm}$ ) $[15,18]$.

- The cross section perpendicular to crista terminalis provides the best morphology but require more sections due to variability of SN position [6]. A fastest technique was also proposed in literature with parallel sections to crista terminalis [16].
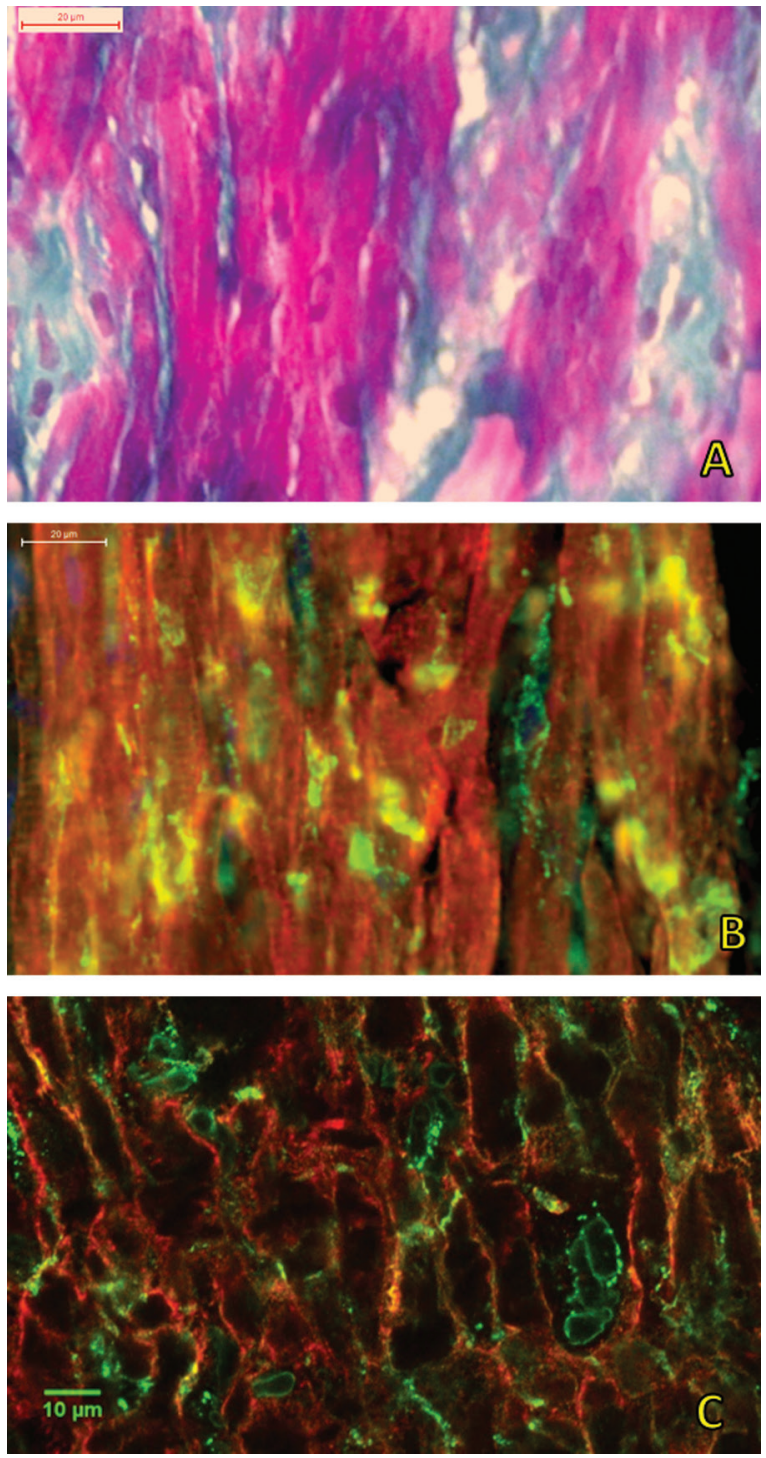

Figure 13. A. Trichrome Masson, $40 \times$, atrial muscle; B. Dual labelling, connexin 43 [Cx43]/caveolin 3 [Cav3], 40×, epifluorescence - atrial muscle, mostly longitudinal cells; C. Dual labelling, $63 \times$, Cx43 (green)/Cav3 (red), confocal microscope atrial muscle, mostly longitudinal cells.

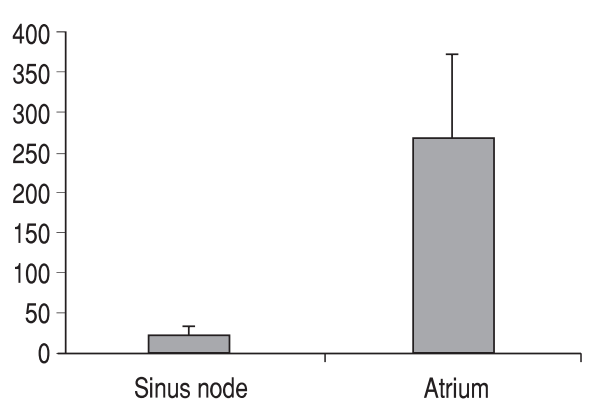

Figure 14. Connexin $43 \mathrm{IHC}$ semiquantification comparison $(p<0.05)$. 


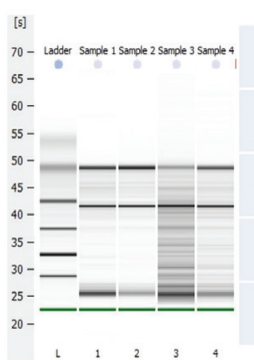

\begin{tabular}{|c|c|}
\hline sample & RIN \\
\hline sample 1 & 7.9 \\
\hline sample 2 & 8.4 \\
\hline sample 3 & 4.3 \\
\hline sample 4 & 6.7 \\
\hline
\end{tabular}

Figure 15. RNA integrity number (RIN) for each sample.

- Rapid orientation on section by reference to the SN artery is quick and useful for sampling for mRNA, but must be confirmed by subsequent adjacent sections (Figs. 7, 8).

- Snap freezing at $-65^{\circ} \mathrm{C}$ in isopentane and preservation is easier than using liquid nitrogen at $-80^{\circ} \mathrm{C}$ and with similar protein expression and gene mRNA conservation.

- Classical histological staining with Masson Trichrome provides a good contrast between pink myocardial cells and blue connective tissue, but does not precisely differentiate fibroblasts from nodal cells and nodal cells from transitional and working myocytes (Fig. 8).

- Messenger RNA was stable for the first $30 \mathrm{~h}$ postmortem and also after microdissection if the RNAse activity was inhibited $[19,20]$.
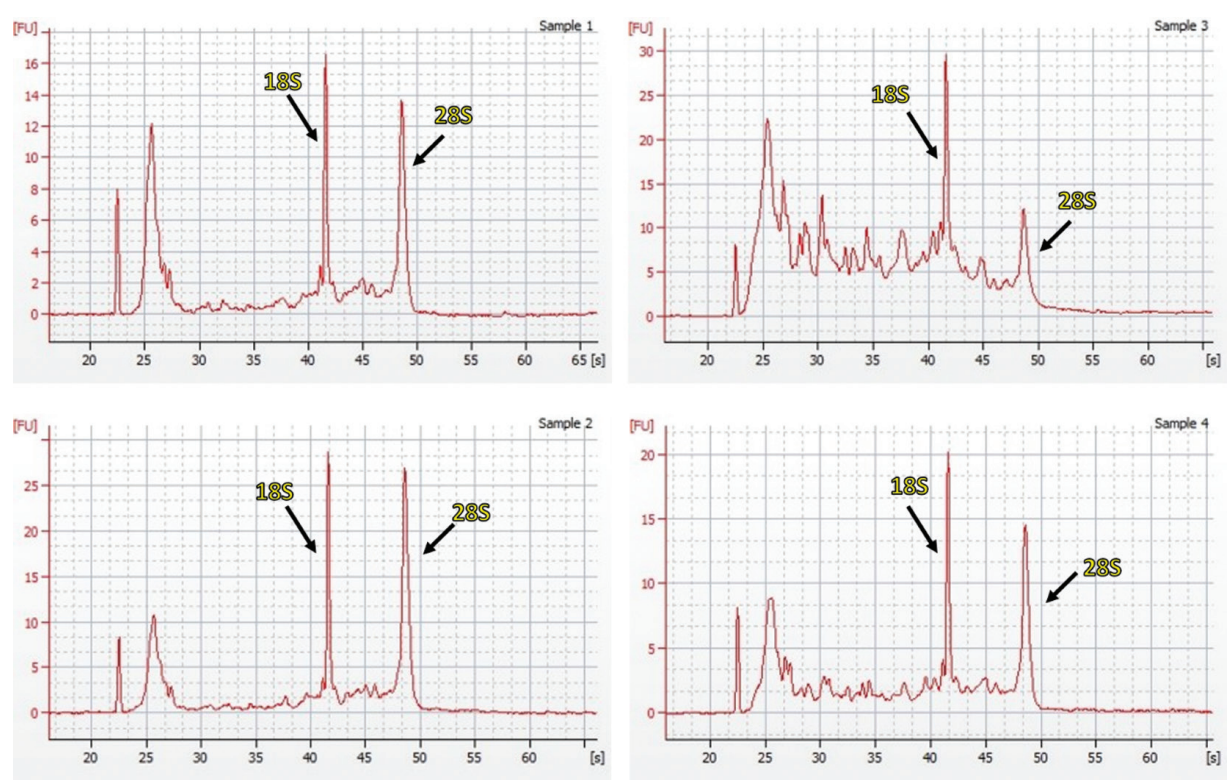

Figure 16. Comparison of $18 \mathrm{~S}$ and $28 \mathrm{~S}$ for each sample.

- The best contrast is offered by immunohistochemical double staining with red cell membranes (Cav3) and intercellular junctions with green (Cx43). At overlapping places yellow appearance occurs. In the SN, myocytes are much smaller, being revealed the precise shape and size. Confocal microscope offers superior resolution and detail than epifluorescence microscope, especially on frozen sections which are thicker and the signal is altered by signal summation; Is also important how the section plane is reported to myocytes long axis (transversal/longitudinal/oblique), because it can give a false signal intensity variation, requiring several sections and an average signal calculation.

- Statistical interpretation was performed after background correction and artefacts removal confirming semiquantitatively what was visually directly seen (Figs. 12, 14). 


\section{CONCLUSIONS}

This study attempted and succeeded to apply various techniques of investigation of the $\mathrm{SN}$, in order to emphasize the feasibility of morpho-functional characterisation of the cadaveric tissue. We identified and localised the $\mathrm{SN}$, a structure considered virtually invisible, by showing anatomic landmarks, histological, immunohistochemical and molecular features, compared to the surrounding atrial tissue. The results, by extension to a broader caseload may allow a developed morpho-clinical correlation involving cardiac arrhythmias. An ideal technique does not exist, being necessary a comprehensive approach in order to characterise the $\mathrm{SN}$ in particular and cardiac conduction system in general: dissection microdissection, immunohistochemistry and gene expression.

\section{ACKNOWLEDGEMENTS}

This paper is supported by the Sectoral Operational Programme Human Resources Development (SOP HRD), financed from the European Social Fund and by the Romanian Government under the contract number POSDRU/159/1.5/S/137390.

\section{REFERENCES}

1. Anderson KR, Ho SY, Anderson RH (1979) Location and vascular supply of sinus node in human heart. Br Heart J, 41: 28-32. doi: 10.1136/hrt.41.1.28.

2. Bauer M, Gramlich I, Polzin S, Patzelt D (2003) Quantification of mRNA degradation as possible indicator of postmortem interval: a pilot study. Legal Med, 5: 220-227. doi: 10.1016/j.legalmed.2003.08.001.

3. Bonow RO, Mann DL, Zipes DP, Libby P (2011) Braunwald's Heart Disease: A Textbook of Cardiovascular Medicine, 2-Volume Set. Saunders, Philadelphia.

4. Boyett MR, Inada S, Yoo S, Li J, Liu J, Tellez J, Greener ID, Honjo H, Billeter R, Lei M, Zhang H, Efimov IR, Dobrzynski H (2006) Connexins in the sinoatrial and atrioventricular nodes. Adv Cardiol, 42: 175-197. doi: 10.1159/000092569

5. Chandler N, Aslanidi O, Buckley D, Inada S, Birchall S, Atkinson A, Kirk D, Monfredi O, Molenaar P, Anderson R, Sharma V, Sigg D, Zhang H, Boyett M, Dobrzynski H (2011) Computer three-dimensional anatomical reconstruction of the human sinus node and a novel paranodal area. Anat Rec, 294: 970-979. doi: 10.1002/ar.21379.

6. Chandler NJ, Greener ID, Tellez JO, Inada S, Musa H, Molenaar P, Difrancesco D, Baruscotti M, Longhi R, Anderson RH, Billeter R, Sharma V, Sigg DC, Boyett MR, Dobrzynski H (2009) Molecular architecture of the human sinus node insights into the function of the cardiac pacemaker. Circulation, 119: 1562-1575. doi: 10.1161/circulationaha.108.804369.

7. Christoffels VM, Smits GJ, Kispert A, Moorman AF (2010) Development of the pacemaker tissues of the heart. Circ Res, 106: 240-254. doi: 10.1161/circresaha.109.205419.

8. Dobrzynski H, Anderson RH, Atkinson A, Borbas Z, D'Souza A, Fraser JF, Inada S, Logantha SJ, Monfredi O, Morris GM, Moorman AF, Nikolaidou T, Schneider H, Szuts V, Temple IP, Yanni J, Boyett MR (2013) Structure, function and clinical relevance of the cardiac conduction system, including the atrioventricular ring and outflow tract tissues. Pharmacol Ther, 139: 260-288. doi: 10.1016/j. pharmthera.2013.04.010.

9. Dobrzynski H, Boyett MR, Anderson RH (2007) New insights into pacemaker activity promoting understanding of sick sinus syndrome. Circulation, 115: 1921-1932. doi: 10.1161/circulationaha.106.61601.

10. González-Herrera L, Valenzuela A, Marchal JA, Lorente JA, Villanueva E (2013) Studies on RNA integrity and gene expression in human myocardial tissue, pericardial fluid and blood, and its postmortem stability. Forensic Sci Int, 232: 218-228. doi: 10.1016/j. forsciint.2013.08.001.

11. Heinrich M, Lutz-Bonengel S, Matt K, Schmidt U (2007) Real-time PCR detection of five different "endogenous control gene" transcripts in forensic autopsy material. Forensic Sci Int Genet, 1:163-169. doi: 10.1016/j.fsigen.2007.01.002.

12. Heinrich M, Matt K, Lutz-Bonengel S, Schmidt U (2007) Successful RNA extraction from various human postmortem tissues. Int J Legal Med, 121: 136-142. doi: 10.1007/ s00414-006-0131-9.

13. James TN (1970) Cardiac conduction system: fetal and postnatal development. Am J Cardiol, 25: 213-226. doi: 10.1016/0002-9149(70)90581-3.

14. Keith A, Flack M (1907) The form and nature of the muscular connections between the primary divisions of the vertebrate heart. J Anatom Physiology, 41 (Part 3): 172.

15. Ludwig J (2010) Handbook of autopsy practice. Humana Press Totowa, NJ. http://dx.doi.org/10.1007/978-1-59259$-286-9$.

16. Michaud K, Romain N, Taroni F, Horisberger B, Mangin $P$ (2002) Evaluation of a simplified method of the conduction system analysis in 110 forensic cases. Forensic Scien Int, ce 130: 13-24. http://dx.doi.org/10.1016/s03790738(02)00269-4.

17. Monfredi O, Dobrzynski H, Mondal T, Boyett MR, Morris GM (2010) The anatomy and physiology of the sinoatrial node: a contemporary review. Pacing Clin Electrophysiol, 33: 1392-1406. doi: 10.1111/j.1540-8159.2010.02838.x.

18. Oliva A, Brugada R, D'Aloja E, Boschi I, Partemi S, Brugada J, Pascali VL (2011) State of the art in forensic investigation of sudden cardiac death. Am J Forensic Med Pathol, 32: 1-16. doi: 10.1097/PAF.0b013e3181c2dc96.

19. Partemi S, Berne PM, Batlle M, Berruezo A, Mont L, Riuró $H$, Ortiz JT, Roig E, Pascali VL, Brugada R, Brugada J, Oliva A (2010) Analysis of mRNA from human heart tissue and putative applications in forensic molecular pathology. Forensic Scien Int, 203: 99-105. http://dx.doi.org/10.1016/j. forsciint.2010.07.005.

20. Partemi S, Coll Vidal M, Campuzano O, Pezzella M, Paravidino R, Pascali VL, Tassinari CA, Striano S, Zara F, Brugada R, Striano P, Oliva A (2013) Importance of post-mortem genetic testing in SUDEP patients. Forensic Scien Int, Genetics Supplement Series, 4: e354-e355. http://dx.doi. org/10.1016/j.fsigss.2013.10.180.

21. Preece $P$, Cairns NJ (2003) Quantifying mRNA in postmortem human brain: influence of gender, age at death, postmortem interval, brain $\mathrm{pH}$, agonal state and inter-lobe mRNA variance. Mol Brain Res, 118: 60-71. doi: 10.1016/ s0169-328x(03)00337-1.

22. Vennemann M, Koppelkamm A (2010) Postmortem mRNA profiling II: Practical considerations. Forensic Scien Int, 203: 76-82. doi: 10.1016/j.forsciint.2010.07.007.

23. Vilallonga JR (2003) Anatomical variations of the coronary arteries: I. The most frequent variations. Eur J Anat, 7: 29-42.

24. Yasojima K, McGeer E, McGeer P (2001) High stability of mRNAs postmortem and protocols for their assessment by RT-PCR. Brain Res Protocols, 8: 212-218. doi: 10.1016/ s1385-299x(01)00119-2. 